\title{
UNDERSTANDING THE CONSUMER
}


Also by David A. Statt

PSYCHOLOGY: MAKING SENSE

THE CONCISE DICTIONARY OF PSYCHOLOGY

THE CONCISE DICTIONARY OF MANAGEMENT

PSYCHOLOGY AND THE WORLD OF WORK 


\section{UNDERSTANDING THE CONSUMER}

A PSYCHOLOGICAL APPROACH

David A. Statt

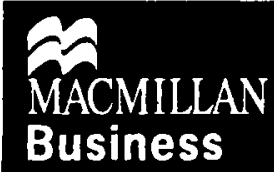




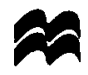

David A. Statt 1997

All rights reserved. No reproduction, copy or transmission of this publication may be made without written permission.

No paragraph of this publication may be reproduced, copied or transmitted save with written permission or in accordance with the provisions of the Copyright, Designs and Patents Act 1988, or under the terms of any licence permitting limited copying issued by the Copyright Licensing Agency, 90 Totenham Court Road, London W1P 9HE.

Any person who does any unathorized act in relation to this publication may be liable to criminal prosecution and civil claims for damages.

The author has asserted his right to be identified as the author of this work in accordance with the Copyright, Designs and Patents Act 1988.

First published 1997 by

\section{MACMILLAN PRESS LTD}

Houndmills, Basingstoke, Hampshire RG21 6XS

and London

Companies and representatives

throughout the world

ISBN 978-0-333-66063-8 ISBN 978-1-349-25438-5 (eBook)

DOI 10.1007/978-1-349-25438-5

A catalogue record for this book is available from the British Library.

This book is printed on paper suitable for recycling and made from fully managed and sustained forest sources.

$\begin{array}{llllllllll}10 & 9 & 8 & 7 & 6 & 5 & 4 & 3 & 2 & 1\end{array}$

$\begin{array}{llllllllll}06 & 05 & 04 & 03 & 02 & 01 & 00 & 99 & 98 & 97\end{array}$


To Elliot and Stan

and all the Brookwood Boys

in celebration

of what we believed in 


\section{Contents}

List of Figures and Tables $\quad$ xii

Preface xv

Acknowledgement $\quad$ xvi

\section{PART I THE CONSUMER IN CONTEXT}

1. People as Consumers 3

Introduction $\quad 3$

Studying People as Consumers 3

The Consumer Environment and the Consuming Society 6

The Consumer and the Market Place 7

Further Reading 11

Questions for Discussion 11

2. Market Segmentation 12

Introduction: The Origin of Segmented Markets 12

Geographic Segmentation 14

Demographic Segmentation 15

Psychological Segmentation 19

Segmentation by Usage 21

Segmentation by Benefit 22

Further Reading 24

Questions for Discussion 24

3. New Products and Innovations

25

Introduction 25

Developing New Products 25

The Product Life Cycle 29

The Effects of Personal Influence $\quad 30$

The Diffusion of New Products and Innovations 32

The Adoption of New Products and Innovations $\quad 34$

Further Reading $\quad 36$

Questions for Discussion $\quad 37$

PART II THE INDIVIDUAL PERSPECTIVE

4. Perception

Introduction
41

41 
Using Our Senses 41

Common Properties of the Senses 44

Perception: Processing Sensory Information 46

Organising Perceptual Cues 51

Subliminal Perception 56

Product Images, Self-Images and Consumer Behaviour

Further Reading $\quad 60$

Questions for Discussion 60

5. Personality 61

Introduction 61

What is Meant by Personality?

Formal Theories of Personality?

Freudian Psychoanalysis

Neo-Freudian Psychoanalysis

69

Self Theory $\quad 70$

Trait Theory 73

Brand Personality 75

Further Reading $\quad 76$

Questions for Discussion 76

6. Learning $\quad 77$

Introduction $\quad 77$

What is Learning? 77

The Behaviourist Approach $\quad 78$

The Cognitive Approach 85

Further Reading 93

Questions for Discussion 93

7. Motivation 94

Introduction 94

What is Meant by Motivation? 94

Defining Motivation 95

The Fulfilment of Needs $\quad 97$

The Motivational Mix $\quad 99$

Unconscious Motivation 105

Semiotics $\quad 108$

Further Reading $\quad 109$

Questions for Discussion 109

\section{PART III THE SOCIAL PERSPECTIVE}

8. Family Influences $\quad 113$

Introduction 113

What is a Family? $\quad 115$ 
Socialization $\quad 117$

Family Buying Decisions

Life Cycle Effects 125

Non-Family Households

Further Reading $\quad 129$

Questions for Discussion $\quad .129$

9. Social and Developmental Influences 130

Introduction $\quad 130$

Maturation 131

Stages of Development 131

Development of Economic Concepts $\quad 136$

External Influences on Consumer Socialization

Further Reading $\quad 143$

Questions for Discussion 144

10. The Influence of Small Groups $\quad 145$

Introduction $\quad 145$

Types of Group 145

Properties of Group Life $\quad 148$

Reference Groups and Consumer Behaviour 156

Further Reading $\quad 159$

Questions for Discussion $\quad 159$

11. The Influence of Social Class

Introduction $\quad 160$

Social Stratification $\quad 160$

Social Status and Symbols $\quad 161$

Life Chances and Life styles 163

Measuring Social Class $\quad 164$

Social Class Categories $\quad 167$

Changing Social Class 171

Marketing and Consumer Behaviour

Further Reading $\quad 173$

Questions for Discussion 173

160

12. Cultural Influences

174

Introduction $\quad 174$

Similarities across Cultures

Differences between Cultures

176

Cultural Values $\quad 179$

Subcultures $\quad 187$

Changes in Culture

190

Further Reading 191

Questions for Discussion 192 
13. Attitudes 193

Introduction $\quad 193$

What are Attitudes?

193

Characteristics and Components of Attitudes

Forming Attitudes $\quad 196$

Theories of Attitudes

Changing Attitudes 202

Attitudes and Behaviour $\quad 204$

Further Reading $\quad 207$

Questions for Discussion 207

\section{PART IV CONSUMER DECISION-MAKING}

14. Communication and Persuasion

Introduction

211

The Importance of Advertising

211

The Process of Communication

Feedback and Evaluation 220

Cultural Factors in Advertising

Further Reading 225

Questions for Discussion 226

15. Approaching a Decision

227

Introduction 227

How People Make Decisions

Heuristics 228

The Consumer Decision-Making Process

Marketing Implications 240

Further Reading 242

Questions for Discussion

\section{2}

16. The Decision and its Consequences

Introduction 243

Stage 4: Purchasing Processes

In-Store Purchasing

243

Buying Behaviour 246

At-Home Purchasing 248

Consequences of the Decision

Further Reading 255

Questions for Discussion

17. The Organization as Purchaser

Introduction 256

The Context of Organizational Behaviour

The Process of Organizational Buying 
Further Reading $\quad 270$

Questions for Discussion 270

\section{PART V CONSUMERISM}

18. Consumer Awareness 273

Introduction 273

Images of the Consumer 273

The History of the Consumer Movement $\quad 276$

American Consumerism $\quad 278$

Further Reading 287

Questions for Discussion 288

19. The Future Consumer 289

Introduction $\quad 289$

The Changing Consumer Experience $\quad 289$

The Producer $\quad 289$

The Market Place 292

The Consumer 295

Further Reading $\quad 301$

Questions for Discussion 301

References $\quad 302$

Name Index 323

Subject Index $\quad 330$ 


\section{List of Figures and Tables}

Figures

1.1 Plan for understanding the consumer 10

3.1 Levitt's total product concept 27

3.2 Product life cycle $\quad 29$

3.3 The time dimension $\quad 34$

3.4 The normal distribution of adoption $\quad 35$

4.1 Distortion of schemas 50

4.2 Length of line illusion 51

4.3 Figure and ground illusion 52

4.4 Grouping 53

4.5 Closure 54

5.1 The Freudian iceberg 64

6.1 The classical conditioning process 80

6.2 Application of classical conditioning 81

6.3 Skinner box 83

6.4 Operant conditioning 83

6.5 The memory system 88

7.1 Motivation and buying behaviour 95

7.2 Components of motivation 96

7.3 Maslow's hierarchy of needs 98

8.1 Socialization as illustrated by Statt Cone $\quad 114$ 
8.2 Movement of an individual through households

8.3 Households and the family cycle 125

9.1 Socialization and individual development

9.2 Understanding conservation

132

10.1 Membership and reference groups

10.2 Asch conformity experiment

12.1 Socialization into national culture

13.1 Attitude components

194

14.1 The process of communication

15.1 The consumer decision-making process

15.2 Problem recognition 232

15.3 Fashion cycles 233

16.1 Continuous decision-making process

$16.2 \mathrm{CS} / \mathrm{D}$ and the consumer decision-making process

17.1 The 'Russian doll' approach to organizational behaviour

17.2 Tall organization (British Civil Service) 262

\section{Tables}

9.1 Marketing manipulation of language

11.1 Coleman's CSI classification 167

11.2 British social classes 170

12.1 Differences between the cultural values of Canadians and Americans 187

13.1 Hypothetical illustration of Fishbein's multi-attribute model

13.2 Hypothetical illustration of Fishbein's behavioural intentions model 220 


\section{Preface}

While this book is intended for use as a text on consumer behaviour, with all the appropriate content and coverage, it should also be accessible to the nonspecialist reader interested in the topic.

It is written by a psychologist using a wide range of ideas and research findings from the psychological and social scientific literature and integrating these with marketing examples throughout. In trying to understand consumer behaviour I have therefore been conscious of the complementary experience of the individual consumer and the individual marketer.

In preparing this book I have engaged with the two disciplines of psychology and marketing very seriously but not, I trust, too solemnly, and that is no doubt reflected in the writing. What $I$ hope is also reflected is how much I enjoyed writing it.

I would like to thank my editor, Jane Powell, for being both professional and pleasant to deal with during the writing of this book. My greatest debt of gratitude, as ever, is to my wife Judith, who performed her usual magic and transformed vast mountains of my illegible scrawl into an elegant typescript with the roughest edges smoothed off. Responsibility for the end product is mine alone.

DAvid A. STATT 
The publishers and author are grateful to Routledge Publishers Ltd for permission to reproduce Figures 6.3 and 8.1 . 